\title{
DEVELOPMENTAL POTENTIAL OF SUPEROVULATED RABBIT OVA
}

\author{
R. R. MAURER, W. L. HUNT*, L. D. VAN VLEGK AND \\ R. H. FOOTE \\ Department of Animal Science, Cornell University, \\ Ithaca, Nere York 14850, U.S.A.
}

(Received 13th September 1967)

The ability of transferred ova to develop normally during the pre-natal and early post-natal periods has received only limited attention in the rabbit (Venge, 1950, 1953). This investigation was undertaken: (1) to determine the pre-natal survival of transferred ova obtained from superovulated and normally ovulated does, and (2) to compare early post-natal development of young rabbits resulting from transferred and non-transferred ova.

Superovulated ova obtained from ten does receiving follicle stimulating hormone and luteinizing hormone (FSH-LH treatment) and from ten does receiving pregnant mares serum and human chorionic gonadotrophin (PMSGHGG treatment) were compared with ova recovered from ten does receiving only LH (Maurer, Hunt \& Foote, 1968). Ova were collected in vivo from anaesthetized does 26 to $32 \mathrm{hr}$ after the injection of LH or HCG and transferred to the recipients within $30 \mathrm{~min}$ of collection. The recipients consisted of thirty-two nulliparous does averaging 25 weeks of age and thirty-four parous does averaging 73 weeks of age. All animals were kept in individual cages at $21^{\circ} \mathrm{C}$ with $12 \mathrm{hr}$ of artificial light daily.

The recipient and donor does were injected simultaneously with the same ovulating hormones $(2.5 \mathrm{mg} \mathrm{LH}$, or 50 i.u. HGG). Each recipient doe was anaesthetized and a flank incision was made. The ova in a small volume of serum were deposited 2 to $3 \mathrm{~cm}$ into the fimbriated end of the oviduct. Normally five ova were transferred to each oviduct of the recipient. Where no more than five ova were available, the ova were deposited in one oviduct and never less than two ova were transferred.

Shortly after the recipient does kindled, the young were counted, earnotched for identification, sexed and weighed. Each recipient doe had her litter size adjusted to six young. The six young consisted of three young from the litter which the recipient doe delivered (young from transferred ova) and three foster young from does bearing their own young following injection of the same ovulating hormone given to the donor of the transferred ova. The fostered young were readily accepted by the foster mothers. Each doe was allowed to raise the young for 2 or 4 weeks, depending upon the available space. Forty-one of the fifty-six litters resulting from transferred ova were

\footnotetext{
* Present address: Department of Endocrinology, Division of Biological Research, G. D. Searle \& Co., P.O. Box 5110, Chicago, Illinois 60680 .
} 
selected for use in the study of post-natal development. Birth weights, 2-week weights and, when possible, 4-week weights were taken on each surviving animal in the forty-one litters. Each doe and her litter were checked twice daily. Survival time for each young up to 2 weeks of age was recorded.

During the experimental period, young born to non-experimental does within the colony were sexed, marked and weighed at birth to provide a standard for comparison with the young from transferred ova and fostered young. The litter size was not adjusted and similar data were collected as described for the young from transferred ova and fostered young. Forty-five litters were raised to 2 weeks of age and twenty-two randomly selected litters were raised to 4 weeks of age by their respective does. The data from the experimental groups were analysed according to procedures described by Steel \& Torrie (1960).

\section{TABLE 1}

POST-NATAL DEVELOPMENT OF YOUNG FROM TRANSFERRED OVA AND FOSTERED YOUNG NURSED BY THE SAME DOE COMPARED WITH THAT OF CONTEMPORARY NONEXPERIMENTAL ANIMALS

\begin{tabular}{|c|c|c|c|c|c|}
\hline \multirow[b]{2}{*}{ Criteria } & \multicolumn{2}{|c|}{ Toung from transferred ova } & \multicolumn{2}{|c|}{ Fostered young } & \multirow{2}{*}{$\begin{array}{c}\text { Non- } \\
\text { experimental } \\
\text { young }\end{array}$} \\
\hline & Original & $\begin{array}{c}\text { Randomly } \\
\text { selected young } \dagger\end{array}$ & Original & $\begin{array}{c}\text { Randomly } \\
\text { selected young } \dagger\end{array}$ & \\
\hline Mean litter size & $5 \cdot 6(231)$ & $3 \cdot 0(123)$ & $5.5(227)$ & $3.0(123)$ & $6 \cdot 4(322)$ \\
\hline Mean birth weight (g) & $50 \cdot 0(231)$ & $50 \cdot 0(123)$ & $50 \cdot 0(227)$ & $50 \cdot 0(123)$ & $45 \cdot 2(322)$ \\
\hline $\begin{array}{l}\text { Sex } \\
\text { Male } \\
\text { Female }\end{array}$ & $\begin{array}{l}109 \\
122\end{array}$ & $\begin{array}{l}56 \\
57\end{array}$ & $\begin{array}{l}125 \\
102\end{array}$ & $\begin{array}{l}70 \\
53\end{array}$ & $\begin{array}{l}148 \\
174\end{array}$ \\
\hline Mortality rate $(\%)$ & - & $29 \quad(123)$ & - & $37 \quad(123)$ & $37 \quad(322)$ \\
\hline Mean 2-week weight (g) & - & $200 \cdot 0(82)^{*}$ & - & $201 \cdot 0(76)^{*}$ & $199 \cdot 0(204)$ \\
\hline Mean 4-week weight $(\mathrm{g})$ & - & $454 \cdot 0(17) \ddagger$ & - & $483 \cdot 0(19) \ddagger$ & $454 \cdot 0(103)$ \\
\hline
\end{tabular}

Numbers in parentheses are the total number of young used to calculate mean values.

* Thirty-three recipient does raised both types of young to 2 weeks of age.

† Three young from each litter resulting from transferred ova and three fostered young were randomly selected to provide the litters of six young.

$\ddagger$ Only eight recipient does were allowed to raise both types of young to 4 weeks of age.

Of the 538 ova transferred, ninety-one were in the 2-cell stage, 371 were in the 4-cell stage and seventy-six were in the 5- to 8-cell stage of cleavage. The average number of ova transferred/recipient in the FSH-LH, PMSG-HCG and LH groups was $9 \cdot 3,8.4$ and 6.6 , with $60 \cdot 1,44 \cdot 8$ and $54.6 \%$, respectively, of the ova transferred developing into young. No significant differences $(P>0.05)$ in the proportion of young developed from transferred ova were detected among treatments and between parous and non-parous recipients. The proportion of pregnant recipients/treatment was as follows: $\mathbf{F S H}-\mathbf{L H}$, twentyfour of twenty-six $(92 \%)$; PMSG-HGG, twelve of seventeen $(71 \%)$; LH controls, twenty of twenty-three $(87 \%)$; and overall treatments, fifty-six of sixtysix $(85 \%)$.

The number of days from transfer of the ova to parturition averaged 30.0 days, and from insemination of the donor to parturition averaged $31 \cdot 2$ days. 
Gestation in non-experimental does in the colony averaged 31.0 days. A total of 293 young developed from transferred ova of which twelve females and fourteen males $(8.9 \%)$ were stillborn. Transferred ova produced $48 \%$ males and $52 \%$ females.

The data on post-natal development of young from transferred ova, on fostered young and for the non-experimental young are summarized in Table 1. Average birth weights in the two experimental groups were similar, but analysis of covariance" showed that litter size did affect the individual birth weight $(P<0.01)$. Body weights at 2 weeks and 4 weeks of age, adjusted for birth weights by covariance analysis, showed no difference $(P>0.05)$ between young from transferred ova and fostered young. Doe differences accounted for $65.7 \%$ of the total variance of the 2-week weights adjusted for birth weights $(P<0.01)$. Treatment, does $\times$ treatment, and residual accounted for $0.6,12.4$

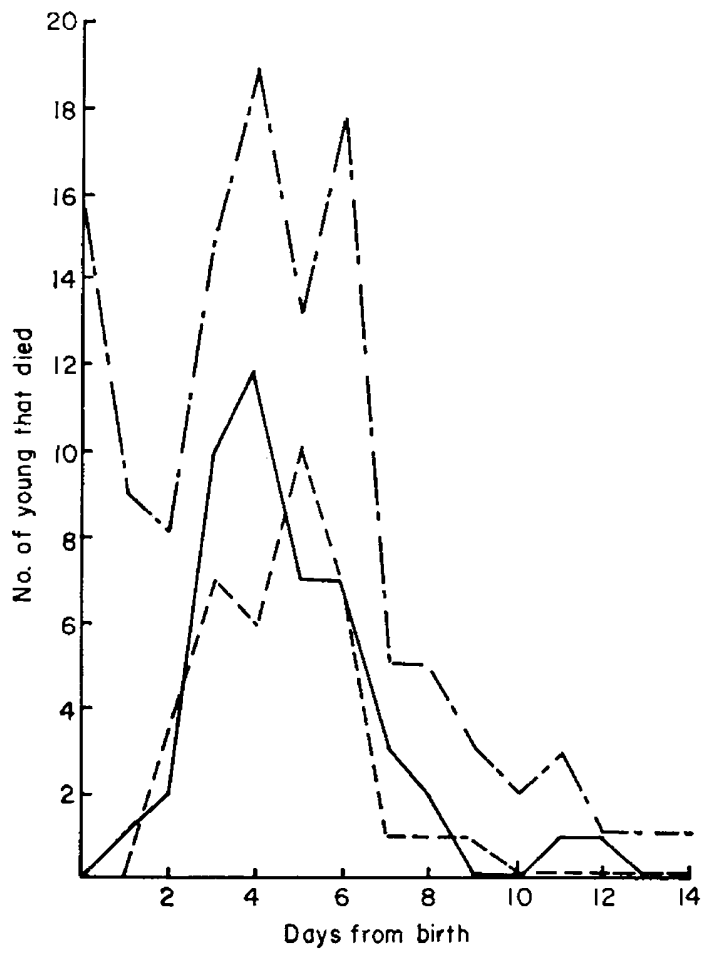

TEXT-FIG. 1. Mortality of young during the first 2-week post-natal period.

-...-..-., 322 non-experimental young; -----, 123 young from transferred ova;

, 123 fostered young.

and $21.3 \%$ of the total variance, respectively. Corresponding analysis of 4 -week weights showed that the four sources of variance contributed $72 \cdot 2,1 \cdot 3,18.4$ and $8.1 \%$ of the total variance, respectively. However, when 4-week weights were adjusted for 2-week weights, the doe differences accounted for only $28.4 \%$ of the total variance $(P<0.01)$ while treatment, does $\times$ treatment and residual accounted for $25 \cdot 8,26 \cdot 7$, and $19 \cdot 1 \%$ of the variance, respectively. The correlation between birth weights and 2-week weights was 0.47 and between 2- and 4-week weights was 0.72 . 
The number of young that died each day up to 14 days of age for the three different groups is shown in Text-fig. 1. Mortality rates were highest between Days 3 and 6 after birth. These appeared to be young which did not nurse or were abandoned by the doe. The mortality rate for the young from transferred ova, fostered young and non-experimental young to 2 weeks of age was $29 \%$ of $123,37 \%$ of 123 , and $37 \%$ of 322 young, respectively. The covariance analysis of days survived adjusted for birth weights showed that there was no significant difference between experimental groups, but a highly significant difference $(P<0.01)$ was noted among does.

Overall, $54.5 \%$ of the superovulated ova developed into viable young. This is similar to $54.5 \%$ obtained by Chang (1948) with fresh rabbit ova, but lower than Dowling (1949), and Avis \& Sawin (1951), who had 79\% and $81 \%$ of transferred superovulated rabbit ova develop into young.

More ova were available for transfer from the donors receiving FSH-LH than from the LH-treated controls. The non-significant difference in the proportion of ova developing suggests that transferring up to ten ova per Dutch-belted recipient did not cause crowding and embryo mortality, and that superovulated ova were as capable of development into viable young as ova obtained by routine ovulation. This is in agreement with Adams (1962) who transferred five ova to each oviduct in 3.5 to $4.0 \mathrm{~kg}$ rabbits without causing a crowded condition in the uterus. Tesh (1966) suggested that eggs produced by superovulation are in some way deficient. However, fertilized ova utilized in this experiment from superovulated donors exhibited normal appearance at transfer, revealed no subsequent defects or deficiencies, and were as capable of development into viable young as ova obtained by routine ovulation.

No differences in development or mortality rates were found between young from transferred ova and fostered young. Both groups of young were similar to the non-experimental group in growth and post-natal mortality.

Most of the variation $(65.7 \%)$ found in the weight of the young at 2 weeks of age adjusted for birth weight was due to doe differences, but this was reduced to $28.4 \%$ between 2 and 4 weeks. This emphasizes that the doe effect on growth of the young is most pronounced during the first 2 weeks when the young have not yet begun to eat solid feed.

This investigation was supported in part by Public Health Service Research Grant GM 10263 from the National Institute of General Medical Sciences. The authors are grateful to Mrs Valerie Turner and Miss Carol Somer for their assistance.

\section{REFERENCES}

Addms, G. E. (1962) Studies on prenatal mortality in the rabbit, Oryctolagus cuniculus: The effect of transferring varying numbers of eggs. $\mathcal{F}$. Endocr. 24, 471.

Avis, F. R. \& SawIN, P. B. (1951) A surgical technique for the reciprocal transplantation of fertilized eggs in the rabbit. F. Hered. 42, 259.

Chang, M. C. (1948) Probability of normal development after transplantation of fertilized rabbit ova stored at different temperatures. Proc. Soc. exp. Biol. Med. 68, 680.

Dowling, D. F. (1949) Problems of the transplantation of fertilized ova. 7. agric. Sci., Camb. 39, 374.

Maurer, R. R., Hunt, W. L. \& Foote, R. H. (1968) Repeated superovulation following administration of exogenous gonadotrophins in Dutch-belted rabbits. F. Reprod. Fert. 15, 93. 
Steel, R. G. D. \& Torrie, J. H. (1960) Principles and procedures of statistics. McGraw-Hill Book Company, New York.

Tesh, J. M. (1966) Effect of time of insemination and superovulation on fertilization in the rabbit. 7. Endocr. 35, xxviii.

Venge, O. (1950) Studies of the maternal influence on the birth weight in rabbits. Acta zool., Stockh. 31,1 .

VeNGE, O. (1953) Studies of the maternal influence on the growth in rabbits. Acta agric. scand. 3, 243. 